\title{
Effectiveness of hydrologically upgraded natural vegetation riparian buffer on stream water quality protection at Uyo municipality cattle market/slaughter, Nigeria
}

\author{
Obot E. Essien \\ Department of Agricultural and Food Engineering, University of Uyo, Uyo, Akwa Ibom State, Nigeria. \\ E-mail: tobessien@yahoo.com. Tel: +234 8023232195.
}

Accepted 30 September, 2012

\begin{abstract}
A hydrologically upgraded secondary bush-fallow was used as natural native vegetation riparian buffer to protect water quality of adjacent stream against organic waste pollution by non-point source (NPS) run-off and abattoir wastewater draining from the cattle market/slaughter lots at the upslope of the buffer in Uyo municipality, Nigeria. Buffer site characteristics and soil properties and the quality of the stream water were investigated; and their data were statistically analyzed using Word SPSS version 17. Paired sample t-test and correlations between properties of buffers's abattoir waste water and stream water were compared. The buffer vegetation was a mix of trees, shrubs and herbaceous plants although, not in a well-structured design. Microbial counts and total organic carbon (TOC) were high on the acidic soil, sufficient for denitrification of soil or root-uptake of nitrate at the market-buffer boundary. Reduction of nitrate across the buffer-floor width was 69 to $82 \%$ with removal efficiency from 18 to $57 \%$ depending on the buffer section and constituent element of waste, and total microbial reduction across the buffer width was up to $99 \%$. Bush-fallow buffer should be redesigned hydrologically and structurally with grass strip berm at the cattle-market border to increase effectiveness of filtering sediments against the high daily loads of generated organic waste.
\end{abstract}

Key words: Assessment, effectiveness, abattoir wastewater, cattle-market, bush-fallow riparian buffer, stream water quality.

\section{INTRODUCTION}

A riparian buffer is a vegetated area (a buffer strip) near a stream, usually forested, which helps shade and partially protect a stream from the impact of adjacent land uses (Wikipedia, 2011) or it is a vegetated area next to water resources that protects water resources from non-point source (NPS) pollution and provides bank stabilization and aquatic and wildlife habitat (Osmond and Gilham, 2002). Land use and non-point source pollution of adjacent stream quality are significantly related and very pertinent in evaluating riparian portions of adjacent terrestrial ecosystems (USDA, 1997; Lowrance et al., 1985).

Riparian buffer functions as interceptor of surface runoff and subsurface flow thereby controlling non-point source pollution by trapping the sediments, removing nutrients, especially nitrogen and phosphorus sediment
(USDA, 1997). It slows down movement of water from upslope (farms, industries, parks, markets and forests etc) thereby reducing pollutants associated with surface water movement. Nitrates, phosphorus and pesticides are equally prevented from reaching surface and groundwater by effective riparian buffers. Nitrate is the source of nitrogen and reaches groundwater as nitrate through surface water percolation; and the lateral flows or groundwater discharge in turn carry the nitrate particulate to surface streams, rivers, springs and lakes. The nitrate should be removed from water. Buffer plants play effective role in soil nitrate removal as the roots in the buffer zone denitrify the nitrogen in nitrate to gas when the groundwater with nitrates enters the zone where plant roots are active or have been active. The plant roots either absorb the nitrates for use as nutrient in plant 
growth or very importantly, provide an energy source for bacteria to convert nitrogen in nitrate to gas, which escapes to the atmosphere in the process. This occurs exclusively in water-saturated and acidic soils where abundant organic matter is present (Osmond et al., 1995, 2002). This was the case reported for North Carolina (Gilliam et al., 1997). Particulate of phosphorus is mainly associated with the finer soil particles (Quinton, 1999) and moves mainly with the sediment by being bonded to the fine sediment particles (Quinton, 1999; Askoy and Kawas, 2005). Riparian buffer slows down the run-off water sufficiently to allow sediments to settle out and also create enough surface area for infiltration to take place rather than move quickly to the adjacent stream (NCSU, 2002). To achieve effective reduction of excess sediment nutrients, the run-off water must spread over the buffer floor rather than move through it in concentrated or channelized flow (Dillaha et al., 1989), because channelized flow does not allow time for settling out of sediment to occur, and such hydrological condition makes the buffer ineffective in pollutant removal (Dillaha et al., 1989). Therefore, the design of buffer parameters is important for its effectiveness (Dosskey et al., 2002).

Design criteria which determine the effectiveness of riparian buffers are many and are as follows: hydrology, buffer width, type of vegetation and management etc. They are valuable parameters for evaluating how riparian buffers effectively control NPS pollution in an urban setting (Allison et al., 2006). The hydrology design enables run-off flow to spread over the buffer sections' floor, preventing the formation of channels and channelized flow. Use of run-off-spreader called troughtrench system, grass berm and porous mulch bunds at the approach area of the buffer have been found effective (Franklin et al., 1992; Khoury-Nolde, 2006). Width is the most important controllable factor for effectiveness of buffer in reducing pollutants and protecting stream quality. In some structures, the buffer width is zoned with different vegetation. Vegetation may be different or mixed and include grass, herbs, shrubs or trees or forest; however, native plants are able to acquit better benefit than alien. Management includes all that is done to ensure sustainability and effectiveness of riparian buffers. Some of these factors are site-specific requirements such as slope and run-off. Effectiveness, therefore, varies with the specific site factors' design and management.

Grass filter strip works best for sediment removal generally, while forested buffer is better for nitrate removal from sub-surface flows; they also require maintenance for effectiveness (Triangle of $\mathrm{J}$. Councils of Governments, 1999; Dillaha et al., 1989; Daniels and Gilliam, 1996). Grasses have a shallower and denser root mat which effectively slow down runoff and trap sediment from the surface soil, while trees have deeper root system which traps and uptake nutrients especially nitrate from groundwater for use in plant growth through denitrification, as well as use the root system to stabilize stream banks and regulate the flow of water to stream (Hawes and Smith, 2005). Native trees and shrubs inspire a "sense of place" and fit into the landscaping need (HRWC, 2011; NCSU, 2002). Thus, riparian buffers should include a mix vegetation native to the region and appropriate to the environment planted (Jontos, 2004). Filtering efficiency increases with width although, not indefinitely, but 5 to $30 \mathrm{~m}$ for water quality protection and 5 to $10 \mathrm{~m}$ for detritus input are recommended width of buffer zones (Jontos, 2004). In the Carolina State and Delaware cases, 60 to $80 \%$ of nitrogen and $65 \%$ of phosphorus in fertilizers from upslope agricultural land use were reduced by riparian buffers (Durham, 2004; Wikipedia, 2011; Lowrance et al., 1995; Hill, 1996). In addition, buffer zone is a good physical barrier to roaming cattle and other large ruminants from grazing in it and causing their treading feet to create footpaths or tracks that could act as channels for concentration of flow, puddling and destabilizing of soils at stream banks and dropping faeces there, all of which destroy the effectiveness of the riparian buffer (Dillaha et al., 1989; Osmond, 2002; Terrel, 2010).

The considerations made in the foregoing were applied to a natural vegetation riparian buffer to assess its effectiveness in protecting the quality of adjacent secondorder stream water in the Peri-urban area of Uyo municipality, Nigeria. The buffer vegetation was a secondary bush-fallow, forming part of the mixed vegetation used by Iba Oku community for rain-fed upland shift cultivation. However, urbanization expansion has caused an animal (cattle and goat) market and abattoir to be constructed at the upslope area of about $1500 \mathrm{~m}^{2}$, leaving the down-slope strip as a natural native vegetation buffer zone with some hydrological design adjustment. Since the construction of the animal market, no known investigation was undertaken of its effecttiveness on protecting the adjacent stream from polluting drainage water from the market/park.

The existence and conditions at the cattle market/slaughter produced enormous organic wastes from the dynamic interactions of the cattle/goats, goods, traders and nomads and their food and feeds. The goat droppings, cattle dung, poultry frass, litters of dry or stale and soiled straws, hay silage or grass were dropped on the lots' ground or were cleaned, dumped or burned at the border of the market with the buffer strip. Drops of oil, grease and fuel, and fumes particulate settled on the lots ground before they were washed by NPS overland flow to the adjoining river through the buffer width. Old tires were also used to burn the slaughtered animals or parts, leaving ashes at the edge of the buffer which was also washed into the buffer. The unregulated flow of NPS runoff was not checked from carrying its non-point pollutants into the drainage stream. If the sediments and nutrients, particularly phosphorus and nitrogen components, reached the river, the aquatic plant would use them to produce algal bloom that would suffocate biotic or fish 
lives and impair water quality by eutrophication, sedimentation and microbial colonization (Nathanson, 2006).

By allowing a strip of native vegetation bush-fallow between the lot and the stream, sediments and nutrients buffering was expected to take place and protect the stream water quality just as natural vegetation riparian buffer could offer. Hence, the effectiveness needs to be assessed. Therefore, the objectives of the study were: (1) To assess the hydrology design, width, vegetation and other site characteristics of the bush-fallow buffer; (2) to investigate the pollution status of buffer floor soil and adjacent drainage stream, and (3) to evaluate the effectiveness of the riparian buffer on protecting the stream water quality.

\section{MATERIALS AND METHODS}

\section{Site description}

The natural vegetation riparian buffer with an area of $15000 \mathrm{~m}^{2}$ (that is, $30 \mathrm{~m}$ width $\times 500 \mathrm{~m}$ length maximum), was situated in Uyo Local Government Area of Nigeria within longitude $5^{\circ} 02^{1} \mathrm{E}$ and latitude $4^{\circ} 03^{1} \mathrm{~N}$. It is in the equatorial rain-forest belt and houses tropical vegetation of green foliage trees, shrubs, grasses and oil palm trees.

\section{Site preparation}

Pre-experiment investigation was carried out to determine soil type, slope, vegetation and width of buffer; and a level spreader trench was prepared for hydrology upgrade. Width of transverse crosssection was measured with surveyor tape both at the ridged and the flat floor portions of the terrain from the edge of the park/market to the bank of the drainage stream. The lateral or axial length was also measured at the two ends of the bush-fallow. During land clearing and rough-grading, the dozers' blade and tract marks avoided up-and-down-slope alignment of tractor tracks but aligned them laterally across the slope on the contours, so as to prevent such tracks from becoming preferential pathways later for erosive concentrated run-off and rill erosion under the usually heavy rainfall (De Wrachien and Chisci, 1999). No deep cutting and filling was permitted so as to avoid soil mass-wasting. A riparian strip was equally cleared of bush and winnowed without grading the land but allowed to re-grow its native plants. Land-slope was measured with Abney-level and found to be moderate at 2 to $5 \%$, but closer to the drainage stream, it varied between 5 and $16 \%$.

Soil type was obtained from particle size analysis of soil samples from three plots in the buffer area and two plots on the market ground. The expertise of the forester from the University of Uyo was used to identify the types of plants in the buffer. Topography of the fallow was determined by taking levels around its periphery, along with the levels at the open space animal park and market. This also was compared with the feasibility report covering coastal areas including the buffer riparian area (SLUS-AK1989).

\section{Soil sampling}

Three contiguous sections of the buffer were selected for soil sampling to study any spatial difference along the buffer length. They were: the area near animal roasting and waste burning place (CRS), the slaughter of down-slope area (SLT) and the solid waste dump area (MDS). At each section, three stations were selected longitudinally across the buffer width and soil samples were augured there to observe the spatial variation in property across the buffer width due to the filtering of sediment and nutrient particulates by the buffer floor. The stations were at the market edge (MK); at the middle section (MI) and at the stream bank end (SB) of the buffer. Also, two control stations at the cattle pen (CHP) and goat yard (GTS) within the market ground were sampled for comparative analysis. Replicate sampling was spread out for five months mostly in the rainy sessions.

\section{Hydrology upgrade}

When the area for the park/market was cleared in 2004, the high spots at the down-slope were cut and smoothened. In 2007, a long narrow trench of $\mathrm{V}$-shape, (which is a level spreader ditch, Franklin et al., 1992; NCSU, 2002), was cut along the edge of the re-grown bush-fallow vegetation adjacent the animal park/market; sand deposition, which suggested that the run-off flow had become subcritical and slowed down, was observed there after the rain. Also, a grass strip of 90 to $150 \mathrm{~cm}$ was allowed to grow between the edge of the spreader and buffer. Therefore, the effectiveness of the buffer was evaluated against the background that had the runoff flow, though it was not concentrated as a channelized flow. Gully was not observed at the stream-bank end of the buffer also. Run-off from the market ground and at the edges of the buffer was measured and compared in magnitude.

\section{Organic matter content}

Organic carbon content (OMC) was determined by wet oxidation method of Walkley-Black (1934) which gives OMC as $1.724 \times$ organic carbon where 1.724 is Van Bremmelon factor based on the assumption that OMC contained approximately $58 \%$ of carbon.

\section{Soil erodibility}

Soil erodibility depends on the physical properties of the soil under the land management practiced. Bouyoucos (1935) presented it as a ratio of the mechanical composition sand, silt and clay of the soil or as:

Erodibility, $E=(\%$ sand $+\%$ silt $) /(\%$ clay $)$

Morgan (1978) used erodibility factor $k$ as an index which represented soil loss per unit of rainfall intensity $\left(\mathrm{El}_{30}\right)$ as measured under a standard bare soil plot (22 $\mathrm{m}$ and $5^{\circ}$ slope). The market/park terrain fit this background. Thus, we have:

Erodibility factor, $\mathrm{k}=2.8 \times 1010^{-7} \mathrm{M}^{1.4}\left[(12-\mathrm{a})+4.3 \times 10^{-3}(\mathrm{~b}-2)+\right.$ $3.3 \times 10^{-3}(c-3)$

where, $M=$ particle size parameter $=\%$ silt $+\%$ very fine sand $(100$ - \% clay); $a$ is \% organic matter; $b$ is soil structure code given as follows: (1: very fine granular; 2 : fine granular; 3 : medium or coarse granular; 4: blocky; platy or massive); $\mathrm{c}$ is profile permeability class given as (1: fast; 2: moderate to rapid; 3 : slow to moderate; 5: slow, 6: very slow).

Properties of water and effluent utilized standard methods (Ademorati, 1996; APHA, 1985) while other soil chemicals were determined by methods described by Klute (1986).

\section{Statistical analysis}

Descriptive and inferential statistics of the physico-chemical data were statistically analyzed using SPSS software 17.0. 
Table 1. Mean Particle size distribution of soil at the Uyo cattle market/slaughter.

\begin{tabular}{lccccc}
\hline Market location & Sand (\%) & Silt (\%) & Clay (\%) & Silt/Clay ratio & Texture \\
\hline $\mathrm{CRS}$ & $93.69 \pm 1.15$ & $0.00 \pm 0.00$ & $5.64 \pm 0.00$ & 0.00 & $\mathrm{CS}$ \\
$\mathrm{SLT}$ & $94.10 \pm 1.10$ & $2.03 \pm 0.06$ & $3.53 \pm 1.18$ & 0.58 & $\mathrm{CS}$ \\
$\mathrm{MDS}$ & $85.40 \pm 2.00$ & $19.40 \pm 2.30$ & $35.66 \pm 4.5$ & 0.55 & $\mathrm{SCL}$ \\
$\mathrm{X}_{\mathrm{GM}}$ & $91.00 \pm 1.32$ & $7.14 \pm 7.7$ & $8.92 \pm 3.74$ & 0.80 & $\mathrm{SL}$ \\
$\mathrm{X}_{\mathrm{AM}}$ & $91.06 \pm 1.38$ & $7.14 \pm 7.7$ & $14.95 \pm 15.21$ & 0.47 & $\mathrm{SL}$ \\
$\mathrm{CV}$ & 1.5 & 107.8 & 101.7 & 42 & \\
$\mathrm{~F}^{*}$ & $39.029^{\star *}$ & 1.611 & 1.273 & & \\
\hline
\end{tabular}

**, Very significant at p: $0.01 ; \mathrm{X}$, means; GM, geometric mean; AM, arithmetic mean; CS, clayey sand; SL, sandy loam texture; $F^{*}, F-$ ratio (ANOVA).

\section{Assessment of buffer performance}

Buffer performance effectiveness was assessed based on the following criteria:

Proportional reduction $=\frac{\text { Value of property at stream bank soil }}{\text { Value of property at cattle }- \text { Market edge soil }}$

This is a ratio of particulate removal by buffer width. Efficiency of buffer effective pollutant removal (Lowrance et al., 1995; Osmond et al., 2002) is given as:

Buffer percentage removal $=1-($ input value/ output value $)$

Value at market edge - value at bank station

Value at market edge

Stream bank station was at station MK, and market edge at SB. From US Army Corps of Engineer (1991) we have:

Buffer width factor $=(\text { average slope } / \text { erodibility factor })^{1 / 2}$

The values for 5 to $30 \mathrm{~m}$ were compared with observed values from previous experiments (Jontos, 2004).

\section{RESULTS AND DISCUSSION}

\section{Buffer site characteristics}

The landform was mostly rolling down-slope, undulating laterally with a cross-section shape that comprised two low, longitudinally-sloping ridges interspaced by a flat terrain with moderate down-slope also. The vegetation was a mix of herbaceous plants, trees and undergrowth shrubs.

Herbaceous plants occupied mostly the upper edge adjacent to the market place and the strip adjacent to the stream bank, while few pillar trees dotted inside it with herbs and shrubs around them. The vegetation was a regrown fallow with native plants after the land was cleared in 2004. Previously, the cattle trod in the bush-fallow grazing grasses especially in the dry season was stopped in 2007 when the adverse effect of animal tracks on the hydrology of the buffer was mentioned to the Environmental Ministry and the market managers. However, grazing of the elephant grasses at the inland periphery of the buffer went on occasionally, manicuring the edges of the buffer. The buffer's three physiographic sections are contiguous. The width of the buffer varied along its lateral axis between 18 and $29 \mathrm{~m}$, which dimension was adequate for particularly water quality protection, stream bank stabilization and detrital input (Jontos, 2004; Wikipedia, 2011; Lowrance et al., 1995).

Slope varied between 5 to $16 \%$ on the buffer area in all three contiguous sections. Thus, for CRS, slope was 5 to $15 \%$; for SLT, slope was 2 to $5 \%$ and $12 \%$; and for MDS, slope was $15 \%$. Soil type varied from sandy clay loam in topsoil to sandy clay subsoil with texture of the following ranges: sand: not variable, 7.00 to $86.00 \%$; silt: highly variable, 1.40 to $9.40 \%$; clay: highly variable, 12.6 to $20.6 \%$ and ratio of mean texture was $76: 7: 17 \%$ for sand: silt: clay, hence giving sandy clay loam texture (Table 1). Highest particle sizes were obtained at MDS station (Table 1). Also, silt and clay were highest at MDS, showing soil deposition to be greatest there. These depositions reflect run-off slow-down and spreading as it entered the buffer farm.

\section{Erodibility, Er}

From Equation 1, erodibility was obtained using particle size distribution data in Table 1 as $16.73 \%$ at CRS, $27.23 \%$ at SLT, and $2.94 \%$ at MDS. This indicated a low erodibility on the cattle market ground generally but very low at MDS.

\section{Buffer width $\left(W_{b}\right)$ assessment}

Two methods were used which are as follows:

1. From Equation 8 , at SLT, with $5 \%$ slope and erodibility factor of $27.23 \%$ (or 0.2723 ), $W_{b}=4.285 \mathrm{~m}$; but with $12 \%$ slope and Er of $27.23 \%, W_{b}=6.638 \mathrm{~m}$. Hence total $W_{b}=$ 
Table 2. Typical values of organic matter, organic carbon, Total N, available phosphorus and soil particles at cattle market soil near riparian buffer.

\begin{tabular}{|c|c|c|c|c|c|c|c|c|c|c|c|}
\hline $\begin{array}{l}\text { Depth } \\
\text { (cm) }\end{array}$ & $\mathrm{pH}\left(\mathrm{H}_{2} \mathrm{O}\right)$ & $\mathrm{EC}\left(\mathrm{Ds} / \mathrm{cm} \times 10^{-3}\right)$ & $\begin{array}{c}\text { Organic } \\
\text { carbon (\%) }\end{array}$ & $\begin{array}{c}\text { Organic } \\
\text { matter (\%) }\end{array}$ & $\begin{array}{c}\text { Tot. N } \\
(\%)\end{array}$ & $\begin{array}{c}\text { Av. P } \\
(\mathrm{mg} / \mathrm{kg})\end{array}$ & $\begin{array}{l}\text { CS } \\
(\%)\end{array}$ & $\begin{array}{l}\text { FS } \\
(\%)\end{array}$ & $\begin{array}{l}\mathrm{SI} \\
(\%)\end{array}$ & $\begin{array}{l}\mathrm{CL} \\
(\%)\end{array}$ & TE \\
\hline \multicolumn{12}{|l|}{ At GTS } \\
\hline $0-8$ & 5.19 & 33.5 & 3.02 & 5.21 & 0.26 & 56.7 & 68.2 & 12.4 & 7.4 & 12.0 & SL \\
\hline 8-32 & 4.75 & 43.3 & 1.91 & 3.29 & 0.16 & 46.7 & 42.8 & 34.6 & 6.6 & 16.0 & SL \\
\hline \multicolumn{12}{|l|}{ At SLT } \\
\hline $0-25$ & 4.52 & 42.8 & 2.8 & 4.82 & 0.14 & 9.31 & 75.1 & 16.3 & 2.6 & 6.0 & SL \\
\hline
\end{tabular}

CS, Coarse sand; FS, fine sand; SI, silt; CL, clay; TE $\equiv$, texture.Tot. N, total nitrogen; Av.P, available phophrus.

$10.923 \mathrm{~m}$. At CRS, with $5 \%$ and $15 \%$ slopes, on contiguous terrains, and $\mathrm{Er}=16.61$, hence; $\mathrm{W}_{\mathrm{b}}=5.486+$ 9.503 , or $W_{b}=14.989 m$. At MDS, with $15 \%$ slope in forested buffer, $W_{b}=12.98 \mathrm{~m}$.

2. Using simple models of the US Army Engineers Corp (1991) which accounts for slope, buffer width was obtained by applying 2 feet $(610 \mathrm{~mm})$ per percent slope. Two contiguous slopes were involved especially at CRS with 5 and $15 \%$, giving a total of $20 \%$ (that is, $5 \%+15 \%$ )

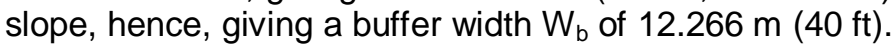
Slopes at SLT were (5 and 12\%) and gave $\mathrm{W}_{\mathrm{b}}$ of $17.28 \mathrm{~m}$ while at MDS with $15 \%, W_{b}$ was $4.07 \mathrm{~m}$. The buffer width varied between 15 and $29 \mathrm{~m}$ inclusive and was sufficient for use. Widths of between 5 and $30 \mathrm{~m}$ (Jontos, 2004) were recommended for vegetated riparian buffers provided that slope greater than 15\% (Wikipedia, 2011) or $25 \%$ (Wenger, 1999) was excluded. Both methods satisfied minimum $\mathrm{W}_{\mathrm{b}}$ as $14 \mathrm{~m}$ at CRS, $10.9 \mathrm{~m}$ at SLT and $13 \mathrm{~m}$ at MDS section of buffer are in harmony with the recommendations of Jontos (2004).

\section{Soil properties at cattle market/slaughter's soil}

Typical values of soil properties at the cattle market/slaughter ground are shown in Table 2, and indicate lower values than obtained at the buffer's soil (Table 3) especially at station MK, the edge of the market bordering the buffer.

\section{Variation of soil properties across buffer width}

Properties of soil at depths and stations across buffer width are shown in Table 3. and varied along buffer sections MDS,SLT and CRS, and across the buffer width. The $\mathrm{pH}$ varied across the width significantly and was low at SLT section (with CV of $26.4 \%$ ) while it was high and homogenous at other sections (CV of $1.6 \%$ ) showing alkaline soil. Acidic environment and moist soil condition, at SLT induced microbial process that increased denitrification of nitrates at sub-surface soil as also observed in the report of Lowrance et al. (1995). The
MDS had alkaline $\mathrm{pH}$ perhaps from the effect of the crude ash from roasting and burning of animal hairs and solid wastes at its place. However, there was no significant difference $(\mathrm{p}<0.05)$ in $\mathrm{pH}$ with soil depth; especially in the 2 to $20 \mathrm{~cm}$ depth (Table 2).

Electrical conductivity was generally high but higher at the buffer edge (MK) with the animal market than at the stream bank end. The high electrical conductivity suggests that the entire soil in the buffer had high potentials for retaining cations on the exchange field, which benefits crop production highly and eventually stream bank stabilization. It is possible the higher EC in soil at MDS was due to the high salinity at the MDS section. EC increased with $\mathrm{Na}$ content which caused salinity level change in soils (Donahue et al., 1983). EC also varied with the depth of soil from the highest in the 2 $\mathrm{cm}$ depth followed by the $10 \mathrm{~cm}$, to the least in the $20 \mathrm{~cm}$, indicating slow rate of decomposition of organic waste and transportation of these elements across the soil profile. The wide variation of EC (CV of 35, 53 and $30 \%$ for CRS, SLT and MDS sites respectively) indicates a change in the salinity level of the soil along the buffer length. Comparatively, the soil at the goat shed (GTS) on the cattle market ground had the highest mean value of $E C$, which was transferred through surface wash offs and lateral flows by NPS run-off to the buffer edge at MDS, (which is the down-slope coordinate on the axis of GTS), hence, causing the highest value of EC at MDS.

\section{Total organic carbon}

In Table 3, the spatial distribution of total organic carbon (TOC) on the buffer varied in the sequence MDS $>S L T>C R S$ in which the highest concentration was at MK station in all the three sections and SB had the least concentrations, while the means were above $2.0 \%$ reported by Miller and Donahue (1990) as soil's critical level for crop production. This implies that the organic wastes increased the organic carbon content of the soils above critical level. The low significant level (5\%), indicated by F-value (1.282), confirms the high organic carbon from the waste. However, at SB, the stream bank 
Table 3. Variation of soil properties at stations across buffer width, showing effective sediment/nutrient reduction by buffer.

\begin{tabular}{|c|c|c|c|c|c|c|c|}
\hline \multirow{2}{*}{ Soil property } & \multirow{2}{*}{ Buffer section } & \multicolumn{5}{|c|}{ Properties at stations across buffer width } & \multirow{2}{*}{$\begin{array}{c}\text { Process } \\
(\%)\end{array}$} \\
\hline & & MK & MI & SB & \pm SD & CV\% & \\
\hline \multirow{3}{*}{$\mathrm{pH}$} & CRS & 7.80 & 7.90 & 7.90 & 0.08 & 1.0 & \\
\hline & SLT & 3.97 & 5.64 & 6.82 & 1.49 & 26.4 & - \\
\hline & MDS & 8.45 & 8.35 & 8.20 & 0.13 & 1.6 & \\
\hline \multirow{3}{*}{$\mathrm{EC}(\mathrm{mS} / \mathrm{cm})$} & CRS & 173.00 & 126.00 & 86.00 & 43.92 & 34.9 & \\
\hline & SLT & 418 & 260.33 & 174.00 & 136.75 & 52.5 & - \\
\hline & MDS & 488.00 & 363.67 & 301.00 & 107.68 & 29.6 & \\
\hline \multirow{3}{*}{ TOC (\%) } & CRS & 5.51 & 4.23 & 2.63 & 1.47 & 34.7 & \\
\hline & SLT & 6.11 & 4.04 & 2.00 & 2.06 & 51.0 & - \\
\hline & MDS & 6.36 & 5.88 & 5.15 & 0.64 & 10.9 & \\
\hline \multirow{3}{*}{$\mathrm{NO}_{3}(\mathrm{mg} / \mathrm{kg})$} & CRS & 225.00 & 181.67 & 155.00 & 37.88 & 20.8 & \\
\hline & SLT & 420.00 & 390.00 & 345.00 & 39.69 & 10.2 & - \\
\hline & MDS & 2.10 & 1.67 & 0.90 & 0.67 & 40.0 & \\
\hline \multirow{3}{*}{$\mathrm{NH}_{4}(\mathrm{mg} / \mathrm{kg})$} & CRS & 37.40 & 31.90 & 28.20 & 4.86 & 15.2 & \\
\hline & SLT & 30.04 & 29.77 & 29.26 & 0.44 & 1.5 & - \\
\hline & MDS & 40.60 & 36.93 & 32.60 & 4.04 & 10.9 & \\
\hline \multirow{3}{*}{$\mathrm{SO}_{4}(\mathrm{mg} / \mathrm{kg})$} & CRS & 104.50 & 99.00 & 96.25 & 4.76 & 4.8 & \\
\hline & SLT & 99.20 & 77.50 & 50.20 & 24.98 & 32.4 & - \\
\hline & MDS & 123.00 & 118.70 & 113.00 & 5.14 & 4.3 & \\
\hline
\end{tabular}

Generally, values at station MK are the highest.

end of the buffer, the low value indicates effective buffering of TOC by buffer width. Organic carbon is a major constituent of most waste particularly those from organic sources. The crude carbon ash at the animal/waste roasting site, CRS, may account for the high TOC at that station (Table 3). The wastewater from abattoir at section SLT did not contain high carbon component, hence its low TOC. Slight variations in organic carbon content of the sources of waste at the stations maybe due to proportions of total dissolved carbon more than other factors, implying that it was easily broken down in the environment by micro-organisms as compared to other constituents with low dissolved carbon. Total organic carbon increased with depth and was generally contained within the top layers of the soil profile since the prime source of organic materials was on the surface soil. The high content of the organic carbon in $20 \mathrm{~cm}$ may be due to the dissolved component of the organic matter found in the soil. Organic matter content, (OMC) (undissolved part) is often found on the first horizon in a raw form. The dissolved component is found underneath, leading to increase in organic carbon with depth. Organic matter converts to organic carbon at the rate of $3.5 \%$ organic matter content to $2 \%$ organic carbon
(Zachar, 1982) or soil organic matter $=1.755 \times$ organic carbon (SMI Analytical, 2001).

\section{Concentration of ammonium ion $\left(\mathrm{NH}_{4}\right)$}

The distribution of $\mathrm{NH}_{4}$ was in the order: MDS> CRS> SLT with highest mean values of $36.93 \pm 4.04 \mathrm{mg} / \mathrm{kg}$, $31.90 \pm 4.55 \mathrm{mg} / \mathrm{kg}$ and $29.77 \pm 0.44 \mathrm{mg} / \mathrm{kg}$ respectively at $\mathrm{Ml}$ station, giving partial covariance coefficients of 11 , 14 and $1 \%$. The distribution pattern of $\mathrm{NH}_{4}$ was quite similar to that of TOC, suggesting that $\mathrm{NH}_{4}$ was mineralized from organic matter only. This variation resulted in an F-value of 9.611 which confirmed that there was a significant difference in $\mathrm{NH} 4$ content of the wastes $(p<0.05)$ compared to a typical value of $9.3 \mathrm{mg} / \mathrm{kg}$. The distributions in 10 and $20 \mathrm{~cm}$ depths were almost similar and were higher than the amount in the $2 \mathrm{~cm}$ depth, being affected by. the rate of mineralization and leaching of $\mathrm{NH} 4$, by rain water. The high rain storm experienced in the area accelerated high leaching of $\mathrm{NH} 4$, leading to higher concentrations at deeper profiles of the soil. Proportional reduction of $\mathrm{NH} 4$ (Equation 3) was $75 \%$, at CRS, the removal efficiency (Equation 5) was 24.6 and 
$2.6 \%$ at SLT and $19.7 \%$ at MDS.

\section{Concentration of sulphate ion $\left(\mathrm{SO}_{4}\right)$}

Concentration of SO4 increased in the order: MDS> CRS> SLT similar to $\mathrm{NH} 4$ distribution and was homogenous ( $\mathrm{CV}=4 \%$ ) with mean values of $118.70 \pm$ $5.14 \mathrm{mg} / \mathrm{kg}, 99.00 \pm 4.76 \mathrm{mg} / \mathrm{kg}, 77.50 \pm 24.97 \mathrm{mg} / \mathrm{kg}$ respectively. The SO4 content was above normal value of $0.2 \mathrm{mg} / \mathrm{kg}$ reported by Landon (1991) due to organic waste; hence, there may be problems of excess sulphate from these waste materials.

\section{Available phosphorus}

Available phosphorus in the cattle market soil, where there were no trees, was higher than the values in the riparian buffer sections, where there were trees and herbs. Typical values were 46.7 to $56.7 \mathrm{mg} / \mathrm{kg}$ at 8 to 32 $\mathrm{cm}$ and 0 to $8 \mathrm{~cm}$ depth, respectively, higher in the market soil (Table 2) than $9.3 \mathrm{mg} / \mathrm{kg}$ at 0 to $25 \mathrm{~cm}$ in the buffer floor at the SLT section (Table 3). These were converted from concentrations of total phosphorus of 593 $\mathrm{mg} / \mathrm{kg}$ at 0 to $8 \mathrm{~cm}$ and $500 \mathrm{mg} / \mathrm{kg}$ at 8 to $32 \mathrm{~cm}$ in cattle market soil (giving conversion rates of 9.56 and $9.34 \%$ respectively); and from a total of $175 \mathrm{mg} / \mathrm{kg}$ at the SLT buffer floor (a conversion factor of only 5.3\%). The changes in total phosphorus and available phosphorus were significant $(p<0.05)$ and increased with percentage clay fraction of the soil. An earlier soil study in the catchment, including the present riparian buffer indicated that for higher clay content (and also the silt content or silt/clay ratio) a higher conversion rate from total phosphorus into available phosphorus was obtained (SLUS, 1989). From that survey, clay content in sandy loam soils was higher at deeper profile (depth $>50 \mathrm{~cm}$ ) but phosphorus was higher at 0 to $30 \mathrm{~cm}$, showing that phosphorus accumulated mostly in the topsoil on bare soil or root zone soil in the forest, where it was being utilized The highly consumed total phosphorus reduced eutrophication prospect in the stream adjoining the cattle market and slaughter, despite the high rate of generation of organic wastes.

The utilization of phosphorus by trees at section SLT of buffer was very high due to its acidic saturated soil $(\mathrm{pH}$ 3.7, Table 3), although, its bacterial colony was lower than the other sections.

\section{Microbial population distribution}

Denitrification is said to be most effective in root zone soil layers when carbon sources are available for denitrifying bacteria to act (Lowrance et al., 1995). The carbon content in the 0 to $20 \mathrm{~cm}$ root zone was 1.9 to $3.0 \%$
(Table 2), good enough for the high microbial bacterial population at the edge of the market (MK, Table 4). Denitrification was effective within the buffer zone 3 to $15 \mathrm{~m}$ from the market edge in line with designs (Lowrence et al., 1995). In this case, it was within the 5 to $28 \mathrm{~m}$ buffer width, showing that the buffer width provided suitable conditions for effective nitrate uptake by roots; hence, reducing microbial count in the stream water despite its high content in the buffer floor soil (Table 4). Microbial population was very high at the cattle market edge by the buffer but went down by 70 to $100 \%$ across the buffer width at the stream bank (Table 4). This caused denitrification at cattle market end and safeguarded stream water quality at the bank end.

\section{Effectiveness of butter on abattoir wastewater filtration}

A comparison of the properties of stream water with those of the polluting source (abattoir wastewater) (Table 5) using paired sample t-statistics indicated a very significant difference at $10 \%$. The concentration of properties of the stream water was significantly $(p<0.10)$ lower than those of the polluting abattoir wastewater indicating that the native bush-fallow (vegetation) riparian buffer functioned effectively in trapping and filtering the high concentrations of pollutants in wastewater effluent to protect the receiving stream quality.

\section{Effectiveness of buffer on nitrate reduction}

Riparian buffers aims to reduce nitrogen, retard sediment and phosphorus and protect the stream quality (Osmond and Gilham, 2002; Osmond et al., 2002). Most nitrogen from agricultural fields reaches surface water as nitrate in the groundwater which drains below the soil surface. Nitrate particulates were very high with $225 \mathrm{mg} / \mathrm{kg}$ at the CRS (the roasting/burning section of the buffer), where acid ash was produced daily by burning contaminated waste straws, goats hairs and old tires (used as fuel wood also); and at slaughter section (SLT) with 420.00 $\mathrm{mg} / \mathrm{kg}$ (the highest on the buffer, Table 3). However, their values dropped at stream bank end (SB) to 155.00 and $345 \mathrm{mg} / \mathrm{kg}$, giving CV of 20.8 and $10.2 \%$ respectively. The difference means that 69 and $82 \%$ proportional reduction of nitrate-nitrogen respectively across the buffer width was achieved. However, the removal efficiency was low at $31 \%$ at CRS section, $18 \%$ at SLT and $57 \%$ at MDS sections. Therefore, the natural mixed vegetation riparian buffer was $68 \%$ effective in nitrate removal but the efficiency of removal was low at $35 \%$ average. This was less than the removal efficiency of $61 \%$ for nitrates in a vegetation mix buffer comprising trees, shrubs and grasses reported by Jontos (2004). The $\mathrm{pH}$ of 3.97 at SLT was adequate condition, but the $\mathrm{pH}$ at $\mathrm{CRS}$ and 
Table 4. Microbial population distribution across buffer width.

\begin{tabular}{|c|c|c|c|c|c|c|}
\hline \multirow{2}{*}{ Parameter } & \multirow{2}{*}{ Location } & \multicolumn{3}{|c|}{ Mean count $\times 10^{2} \mathrm{cfu} / \mathrm{g}$} & \multirow{2}{*}{ F-value } & \multirow{2}{*}{$\%$ reduction } \\
\hline & & MK & SB & \pm SD & & \\
\hline \multirow{3}{*}{ Total count } & CRS & 94.67 & 3.78 & 90.89 & 1.328 & 99.6 \\
\hline & SLT & 24.33 & 5.32 & 19.01 & & 21.9 \\
\hline & MDS & 57.67 & 9.07 & 48.60 & & 84.3 \\
\hline \multirow{3}{*}{ Fungi } & CRS & 4.67 & 0.43 & 4.24 & 1.337 & 90.8 \\
\hline & SLT & 0.00 & 0.00 & 0.00 & & 100.0 \\
\hline & MDS & 5.67 & 3.18 & 2.52 & & 44.4 \\
\hline \multirow{3}{*}{ Bacteria } & CRS & 90.67 & 6.16 & 84.51 & 1.730 & 93.2 \\
\hline & SLT & 21.67 & 6.39 & 15.28 & & 70.5 \\
\hline & MDS & 52.67 & 8.08 & 44.59 & & 84.6 \\
\hline
\end{tabular}

Table 5. Comparison of properties of abattoir wastewater (pollution source) with receiving stream water to show effectiveness of buffer in protecting stream quality at Uyo cattle market/slaughter.

\begin{tabular}{lcccc}
\hline Parameter & Stream water & Abattoir wastewater & L & Sign \\
\hline $\mathrm{pH}$ & $6.27 \pm 0.06$ & 7.30 & -1.912 & $* \star$ \\
$\mathrm{EC}(\mathrm{mS} / \mathrm{cm})$ & $60.13 \pm 0.15$ & 1648 & & \\
Acidity & $29.42 \pm 0.69$ & 80.00 & & \\
Alkalinity & $40.50 \pm 1.55$ & 135.00 & \\
$\mathrm{SO}_{4}(\mathrm{mg} / \mathrm{L})$ & $0.03 \pm 0.01$ & 114.00 & \\
$\mathrm{NO}_{3}(\mathrm{mg} / \mathrm{L})$ & $0.07 \pm 0.11$ & 288.50 & \\
$\mathrm{NH}_{4} \mathrm{mg} / \mathrm{L}$ & $0.02 \pm 0.01$ & 98.20 & \\
$\mathrm{Phosphorus},(\mathrm{mg} / \mathrm{L})$ & & & \\
$\mathrm{DO}(\mathrm{mg} / \mathrm{L})$ & $3.43 \pm 0.49$ & 5.2 & \\
$\mathrm{BOD}_{5}(\mathrm{mg} / \mathrm{L})$ & $3.17 \pm 0.02$ & 1630 & \\
Coliform count & 59 & 350 & \\
\hline
\end{tabular}

${ }^{* *}$, Significant at $10 \%$.

MDS was slightly high resulting in alkaline soil. The high microbial (bacterial) population at CRS and MDS (Table 4) was effective for denitrification. The concentration of nitrate in the stream adjacent to the buffer zone was very small $(0.07 \pm 0.01)$ signifying that the high amount observed in the soil at the entry to the buffer had infiltrated into soil and used by trees in the buffer to grow lusciously rather than migrate through ground water or with NPS run-off to the stream. Hence, the stream quality was effectively protected by the natural riparian buffer.

The sub-surface flow dynamics from upland dominates the drainage flow in the Ikpa drainage basin, which includes this micro watershed and the drainage stream (Essien and Sangodoyin, 2006). Hence, buffering as this sustains environmental quality of streams adjacent organic pollution source in this watershed. However, the high value of nitrate at the stream bank ends at CRS and, particularly, at SLT (Table 3) necessitates improvement on the effectiveness of this natural bush-fallow riparian buffer for efficient nitrate reduction within its present width.

\section{Conclusion}

A mixed native vegetation riparian buffer, hydrologically upgraded with the provision of a trough trench, and lying downstream of a constructed and active municipality cattle market/ slaughter in Uyo, Nigeria was assessed for its buffering effectiveness to protect the adjoining stream water from nitrate migrating from the upstream agrofacility. Properties of the soil across the buffer width were investigated at three contiguous sections along its length and three different stations across its width. Also investigated and statistically compared were properties of polluting wastewater from the slaughter and the stream water. The width and other site's physical characteristics were found suitable for nitrate and sediments buffering compared to available standards. 
Saturated acidic soil and microbial population necessary for effective denitrification of nitrate existed at the slaughter section more than other sections, but pollution concentration of properties were generally significantly higher at the inflow edge than at the streambank edge of the buffer floor with a covariance of up to $32 \%$ especially at the slaughter section, indicating significant pollution reduction by existing native buffer width. Buffering effectiveness for nitrate was $68 \%$ average but removal efficiency varied with a low average of $35 \%$; hence, improvement is necessitated within its present width.

\section{REFERENCES}

Ademorati CM (1996). Standard methods for water and effluent analysis. Foludex Press Ltd, Ibadan, Nigeria. pp. 111-120

APHA-AWWA-WPCF (1985). Standard methods for the examination of water and waste water 16th ed. American Public Health Association, Washington DC, USA.

Allison BE, Fatula SM, Walanski DP (2006). Evaluating riparian buffers for non-point source pollution control in an urban setting using Riparian Ecosystem Management Model, REMM. In: Proceedings hydrology and management of forested wetland. Proc. of international conference, April 8-10, 2006, New Burn, North Carolina. ASABE Publication 701(0406):129-137

Askoy H, Kawas ML (2005). A review of hill-slope and watershed scale erosion and sediment transport models, Science Direct - CATENA 64(Issue 2-3):247-271.

Bouyoucos GJ (1935). The clay ratio as a criterion of susceptibility of soils to erosion. J. Am. Soc. Agron. 27:738-741.

Daniels RB, Gilliam JW (1996). Sediments and chemical load reduction by grass and riparian buffers. Soil Sc. Soc Amer. J. 60: 246-251.

De Wrachien D, Chisci G (1999). Soil conservation: Erosion Control. In: CIGR handbook of agricultural engineering, Vol .1: Land and Water Engineering (eds VanLier HN, Pereira LS, Steiner FR), pp. 184-212.

Dillaha TA, Reneau RB, Lee D, Mostaghini S (1989). Long-term effectiveness of vegetative filter strips for agricultural non-point source pollution control. Trans. ASAE 32(2):513-519

Donahue RL, Miller RW, Sehickama JC (1983). Soils: An introduction to soils and plant growths. 5th ed. Prentice Hall In., Eaglewood, New York.

Dosskey MG, Helmers MJ, Eisenhauser DE, Franti TG, Hougland KD (2002). Assessment of concentrated flows through riparians buffers. J. Soil Water Conserv. 57(6):336-343

Durham S (2004). Riparian buffer effective. South East Farm Press (February), Retrieved from http://en.wikipedia.org/wiki/Riparian-buffer p. 26.

Essien OE, Sangodoyin AY (2006). Analysis of storm water dynamics using ECCRARO Model in Enyong and Ikpa river catchments in South Eastern Nigeria. J. Appl. Sci. Eng. 6(1):39-47.

Franklin EC, Gregory JD, Smolen MD (1992). Enhancement of the effectiveness of forested filter zones by dispersion of agricultural runoff. Water Resources Research Institute of the University of North Carolina, UNC - WRRI - 92 - 270, Raleigh, NC.

Gilliam JW, Parson JE, Mikkelsen RL (1997). Nitrogen dynamics and buffer zones. In: Buffer zones: Their Processes and Potential and Water Protection. Quest Environmental, Harpenden Harts, UK, pp. 54-61.

Hawes E, Smith M (2005). Riparian buffer zones: Functions and Recommended Width. Available as: Eightmile River WilB18065.10001Ta0.0006Tw220012287.1694.693.1401Tm. p..15. Retrieved from http://www.eightmileriver.org/resources/digital_library/appendicies/09 c3_Riparian\%20Buffer\%20Science_YALE.pdf

Hill AR (1996). Nitrate removal in stream riparian zones. J. Environ. Qual. 25:743-755.
Hiwassee River Watershed Coalition Inc, HRWC (2011). Native Plants Publications. http://www.hrwc.net/publications.htm.

Jontos R (2004). Vegetative buffers for water quality protection: an introduction and guidance document. Connecticut Association of Wetland Scientists http://www.ctwetlands.org/Draft\%20Buffer\%20Paper\%20Version\%20 10.doc Accessed on April 52011.

Klute A (1986). Method of soil analysis. Part 1. Physical and mineralogical methods, 2nd Ed. Am. Soc. Agron., Madison WI, pp. 383-411.

Khoury-Nolde N (2006). Rainwater infiltration. Zero-M, fbr, Germany http://www.ercsa.eu/uploads/media/Rainwater-infiltration.pdf

Landon RJ (1991). Classification levels for different elements in soils. www.skb.sc/8de3e42a-669a-42fe-ae3a-820cd680adOc.fodoc

Lowrance R, Altier LS, Newbold JD, Schnabel RR, Groffman PM, Denver JM, Correl DI, Gilliam JW, Robonson JL, Brinsfield RS, Staver KW, Lucas W, Todd AH (1995). Water quality functions of riparian forest buffer sustems in Chesapeake Bay Watershed. EPA 903-R-95-004. Available at http://paw-ag.wsu.edu/AgHorizons/buffer/cb2.html

Lowrance R, Leonard R, Sherida J (1985). Managing riparian ecosystems to control non-point pollution. J. Soil Water Conserv. 40:87-97.

Miller RW, Donahue RL (1990). Organic matter and container media. In: Soils: An Introduction to Plants Growth. 6th ed. Prentice Hall, Englewood Cliffs, NJ, USA. pp. 181-225,

Morgan RPC (1978). Field studies of rain splash erosion. Earth Surface Processes 3:75-99

Nathanson JA (2006). Basic Environmental Technology (Water Supply, Waste Management and Pollution Control), 4th ed., Prentice - Hall of India, New Delhi 110001, pp. 57-121.

North Carolina State University (NCSU) (2002). Riparian buffers: What Are They and How Do They Work? Riparian buffer fact sheets, Department of Science, Biological and Agricultural Engineering, North Carolina State University. Accessed on April 5, 2011 Available at http://www.soil.ncsu.edu/publication/BMPs/buffers.html.

Osmond DI, Gilham JN (2002). Agricultural Riparian Buffers. NC State University Cooperative Extension Services. www.neuse.ncsu.edu/riparian.pdf Accessed on 12/07/11

Osmond DL, Gilliam JW, Evans RO (2002). Riparian buffers and controlled drainage to reduce agricultural non-point source pollution. North Carolina Agricultural Research Service Technical Bulletin 318, North Carolina State University Raleigh, NC Available at www.soil.ncsu.edu/lockers/Osmond-D/web/Riparian Buffers.pdf.

Osmond DL, Spooner J, Line DE (1995). Systems of best management practices for controlling nonpoint source pollution: The Rural Clean Water Programme Experience, Fact Sheet No. 6, NCSU Water Quality Group, North Carolina State University, Raleigh, NC. P .4 Available http://www.water, ncsu.edu/watershedss/info/brochures/six.html

Quinton JN (1999). Detachment and transport of particles-bound P: Process and Prospects for Modeling. Paper presented at the COST ACTION on phorusemanid Meeting. Cordoba, Spain May (1999). pp. 13-15

Slus AK (1989). Physical background soils and landuse ecological problems. Technical report of the task force on soils and landuse survey, Akwa Ibom State. The government printer, Akwa Ibom State Government, Uyo, Nigeria.

SMI Analytical (2011). Soil analysis. SMI Analytical Laboratory Services. Accessed on 11/07/2011. Available at www.smianalytical.co.za/soil-analysis.htm

Triangle J Council of Governments (1999). An introduction to riparian buffers. TJCOG Technical Memo: Riparian Buffer Series, p. 1.

Terrel D (2010). Use of natural vegetative barriers to limit expansion of praire towndog. Available wwW.digitalcommons.unl.edu/cgi/viewcontent:cgi?article-p. 1130
S Army Corps of Engineers (1991). Buffer strips for riparian zon management. Waltham, MA. p. 56 http://naelibrary.nae.usace.army.mil/dp199/ned91039.pdf

USDA (1997). Riparian forest buffer handbook for Chesapeake Bay Watershed. US. Department of Agriculture, Environmental Protection Agency, Forest Service and Northeastern Area State \& Private Forestry, 
NA-TT-02-97. Washington, DC.

Walkley A, Black JA (1934). An examination of the method of determining soil organic matter and proposed modification of the chronic acid titration methods. Soil Sci. 37:29-38.

Wenger S (1999). Review of the scientific literature of riparian buffer width, extent and vegetation. Institute of Ecology, University of Georgia, Athens, GA. Available at www.ncsu.edu/.buffer.html Accessed on 8/12/2010.
Wikipedia (2011). Riparian buffer. Retrieved from http://en.wikipedia.org/wiki/Riparian-buffer.

Zachar DC (1982). Soil erosion. Elservier Scientific Publishing Co., Amsterdam. p. 547 